\title{
Lost in Translation? Multiple Discursive Strategies and the Interpretation of Sustainability in the Norwegian Salmon Farming Industry
}

\section{Bernt Aarset, et al. [full author details at the end of the article]}

Accepted: 17 March 2020 /Published online: 4 April 2020

(C) The Author(s) 2020

\begin{abstract}
The term 'sustainability' is vague and open to interpretation. In this paper we analyze how firms use the term in an effort to make the concept their own, and how it becomes a premise for further decisions, by applying a bottom-up approach focusing on the interpretation of 'sustainability' in the Norwegian salmon-farming industry. The study is based on a strategic selection of informants from the industry and the study design rests on: 1) identification of the main drivers of sustainability, and 2) the application of five different discursive strategies to analyze how the firms maneuver to legitimize 'sustainability' in their conduct. We employ the Critical Discourse Analysis framework, which emphasizes how discourses provide different concepts of meaning. The sustainability concept is assessed based on how sustainability is brought into action by social actors in a legitimate way, and how this action results in sustainable practices. The empirical case of the study is the verbal justification of sustainability practices among representatives of the Norwegian salmon-farming industry. We aim to find out how these representatives translate the rather vague directives of the sustainability concept into legitimate choices that resonate with the firms' contextual environment, hence, how the salmon farmers perceive, explore, interpret, explain, enact, and defend the diverse landscape of sustainability when implementing professional decisions. We found a trend of passive adaptation to external requirements, such as public regulations and regulative requirements from certification bodies. At the same time, there are progressive forces that attempt to improve the sustainability of the farming practices by involvement in research and innovation projects or cooperation with other firms, e.g. the contribution from offshore engineers in developing high seas farms. The strategies outlined and discussed cannot be seen as a typology to categorize the firms. More than one discursive strategy may be involved in one firm's choice, and the strategies may work on different levels.
\end{abstract}

Keywords Norwegian salmon farming · Sustainability · Critical Discourse Analysis · Legitimation

\section{Introduction}

The salmon-farming industry is increasingly challenged by demands to become more sustainable, but what does sustainability mean in the context of aquaculture? Sustainability is a 
modern social construct. It is produced, processed and maintained by formal regulations, informal rules, and committed stakeholders, as well as followers, critics, customers, and opinion makers. Sustainability as a concept received a significant push from the World Commision on Environment and Development and its definition of sustainable development as "... development that meets the needs of the present without compromising the ability of future generations to meet their own needs" (WCED, 1987). Sustainable development has been high on the international agenda since the UN launched its 17 Sustainable Development Goals to be achieved by 2030, which recognize sustainability as a vitally important business goal (United Nations, 2015).

Sustainability is an increasing megatrend and a strong driver for organizational change (Lubin and Esty (2010); see Buchanan et al. (2005) for a review). There is a growing awareness that social and natural systems must be better integrated in order to find solutions that are socially acceptable, while protecting natural resources and still allowing economies to thrive (Elkington, 1994). This requires novel solutions, where day-to-day practices are organized and performed more sustainably. However, sustainability in all its disguises - despite its rather confrontational claim of change - is frequently vague on how to achieve progress and results (Olesen et al., 2011). Improving sustainability is a dynamic process, as it depends on which resources an organization can access and implement. This dynamism also has a potential for conflict, as the outcome does not necessarily comply with overarching authoritative structures. The sustainability strategies of an organization must therefore be explicit about how they contribute to - and comply with — national and international superstructures.

Sustainability is open to interpretation, and its use differs broadly among different sectors and contexts. Hence, firms that employ sustainability practices must make the concept their own (Carson et al., 2015). Sustainability takes on meaning through the firms' incorporation of the concept by using it as a premise for further decisions (Weick et al., 2005). In this study, we apply a bottom-up approach and focus on how sustainability is interpreted in a specific industrial context (de Lange et al., 2012), namely the Norwegian salmon-farming industry.

The study consists of two components. First, we identify and discuss two main drivers of sustainability: 'Do things right', i.e. respond appropriately to regulations, formal requirements, etc., and, 'Do the right things', i.e. respond to emerging concerns for intangible qualities and impalpable market expectations. Second, we apply five different discursive strategies to analyze how the firms maneuver to legitimize the sustainability of their conduct (Grant et al., 2004; Waldorff, 2013). We employ the framework Critical Discourse Analysis (CDA) (Phillips and Hardy, 2002; Wodak and Meyer, 2001) that emphasizes how discourses "provide different senses of meaning, including what to consider as legitimate problems and solutions" (Waldorff, 2013: 284).

The sustainability of an industry is assessed based on how sustainability is transformed into action, in a way that contributes to the industry's social legitimacy (Carson, 2018) and how or to what extent - this action results in sustainable practices. The empirical case of the present study is the verbal justification of sustainability practices among a set of major Norwegian salmon farmers and prominent spokespersons. This justification requires a translation of the rather vague directives of the sustainability concept into legitimate choices that resonate with the firms' contextual environment. Hence, the objective of this study is to shed light on how salmon farmers perceive, explore, interpret, explain, enact, and defend the diverse landscape of sustainability, when implementing professional decisions. Idealized models of sustainability are of limited value if they do not mesh with the reality of the companies that will translate them into policy. The drivers of concrete, sustainable industrial practices may be exogenous, e.g., regulation (Aarset and Jakobsen, 2009), national audit (Christiansen and Jakobsen, 2017), 
or brands (Bronnmann and Asche, 2016). Drivers could also be endogenous, e.g., organic farming initiatives (Bjordal, 2011), or cooperation with environmental organizations (Guerreiro, 2014; Svalestuen, 2013). Sustainability has gained prominence and become increasingly important for the modern salmon-farming industry; the industry has been forced to take a stand (Carson and Rønningen, 2016; Reinertsen and Haaland, 1995).

We take the following fourfold approach: 1) we identify two main drivers of sustainability for Norwegian salmon farmers, 2) we discuss five discursive legitimizing strategies as an analytical tool to understand the language used by salmon farmers in justifying 'sustainability', 3) we describe the methodology, and 4) we present the empirical analysis followed by a discussion of potential models and a conclusion.

\section{Two Drivers of Sustainability}

The Norwegian salmon-farming industry has proven to be a formidable success measured by criteria such as profitability, turnover and export volume. Technological innovations have driven growth in productivity and thus matched the price reduction that follow an increased supply (Asche, 2008). Recently, productivity growth has been reduced, and demand is now the biggest driver for continued industrial growth (Asche et al., 2013). Global demand for food will increase for at least another 40 years (Godfray et al., 2010) as will the demand for seafood as a source of animal protein (World Bank, 2013). Hence, the question is not if aquaculture will grow, but how it will grow. However, the danger of adverse environmental impact due to unchecked growth is significant. Consequently, aquaculture faces enormous challenges in terms of ensuring environmentally sound production practices in the years to come.

The Norwegian aquaculture sector plans for expansive growth (Meld. St. 16, 2014-15). The plans, however, have been met with criticism and claims that the industry fails to meet standards to ensure sustainable aquaculture practices (Haugen et al., 2017). Arguably, an obstacle to achieving this growth is the industry's struggle with social legitimacy, due, in particular, to a number of environmental controversies (Osmundsen and Olsen, 2017). There is a considerable push towards a more sustainable salmon-farming industry, although the definition of what this entails varies with time and place and between different actors. Responding to these challenges demands that the farmers integrate knowledge about consumers and cultures and embed distinct values and meanings into both innovation and production processes (Manniche, 2012).

In day-to-day operations, fish farmers operate on two fronts. The control and regulation approach require formal competence, technical knowledge, and administrative capacity. In the market demand approach, the farmers exhibit their competence as expansive industrial players with knowledge on many levels. These two approaches have in common that they confront the farmers with sustainability requirements.

Traditionally, the Norwegian seafood sector has been managed by a control and regulation approach. The government possessed regulatory 'nuts and bolts' that they have applied to achieve adequate policy goals. This approach is characterized by technology optimism, formal requirements, implementation of regulations, production-volume focus, and national equity policy, i.e. based on relevant metrics. Sustainability has been a matter of 'doing things right' regarding environmental issues such as pollution, feed content, diseases, escapements, antibiotic use and fish welfare (Olesen et al., 2011; St.meld. nr. 19 (2004-2005)) as well as regarding social issues such as workers' rights. 
Following economic turmoil and an institutional breakdown in the 1990s, the government turned away from the nuts-and-bolt strategy and towards a self-reporting control scheme (Aarset and Jakobsen, 2009). After 2000, the government implemented a permit-based program to stimulate the industry to develop innovative and sustainable technologies and to integrate globally-sanctioned sustainability goals, i.e. the Brundtland commission (WCED, 1987) and the UNGD2030 goals (United Nations General Assembly, 2015). In Norway, these initiatives were integrated into national policies with the intent of disseminating the sustainability goals to industry actors (Meld. St. 1, (2017-2018)).

While some early environmental problems faced by the industry (such as the excessive use of antibiotics) were solved, others (such as salmon lice and escapements) did not go away. In an effort to stimulate the industry to find a solution, the government instigated a 'green permit' program in 2013 (FOR-2013-06-24-754, 2013). This permit program defined three different categories of permits: A, B and C. Each salmon-farming company normally controls several permits, and the A and B permits presupposed the redeeming of a conventional permit and converting to be in line with the requirement of a green permit. The applicant was required to test out ways to reduce the environmental impact of the farms, e.g. the use of sterile fish (Fiskeridirektoratet, 2013). The main contribution of this arrangement was that the farmers had to commit to a much stricter regime regarding salmon lice (Hersoug et al., 2019). The program continued until 2015.

In 2015, the government announced the 'development permit' program in an effort to solve the industry's environmental challenges by rewarding salmon farmers who came up with innovative technologies for tackling looming risk factors faced by the industry (FOR-2004-1222-1798, 2004; Nærings- og fiskeridepartementet, 2015; von Krogh, 2016). Among the evaluation criteria was an assessment of the level of potential improvement compared to existing technologies, the impact on sustainability indicators, and the impact on the environment (including fish welfare and fish health), as well as how these considerations could be measured (Fiskeridirektoratet, 2017; Nærings- og fiskeridepartementet, 2016). In contrast to earlier permit programs, no upper limit to the number of possible permits was set. Willingness to share information obtained from the projects was a prerequisite for receiving a permit. The permits were granted free of charge for a period of 15 years. After that the farmer could take over the permit for $10 \mathrm{MNOK}$, or less than $10 \%$ of the going rate (Furuset, 2018). The program halted the intake of new applications in 2017 (Nærings- og fiskeridepartementet, 2017).

Although the exact nature of the 'do things right' approach has evolved over the years, we can see that this approach has an inward focus, in which the firms are encouraged to comply with policy guidelines that encourage developing and employing sustainable behavior.

In contrast, a 'do the right things' approach arose from an awareness among the public of issues such as food safety and fish health, and an intent to stimulate providers to respond responsibly. The question is how the providers meet the sustainability concerns of the consumers. Compliance to formal regulations and policies are often not enough - social responsibility must be demonstrated through explicit communication that reaches the consumer (Ursin et al., 2016). Lehner (2015) sees the retailer as the 'translator' of sustainability discourse. Consumers are increasingly concerned about social and environmental issues, but when it comes to their purchasing behavior, they are restrictive (Carrigan and Attalla, 2001; Peattie, 2010). Retailers have a lot of power over the production and distribution of food in Europe, and are thus in a good position to impact purchasing behavior (Lehner, 2015). Many retailers (?) claim to use this power to increase the consumption of sustainable products. However, if consumers are (notoriously) disloyal and exaggerate the purchase of sustainable 
items, food items labelled sustainable may remain a negligible part of the sales statistics. For the salmon-farming industry, the sustainability requirement is relevant in several arenas, including location, processing, pollution, feed content, feed source, breeding-related issues, open-pen technology, escapees and interaction with wild populations, and transportation. Hence, implementing sustainability may be a risky venture for individual firms (e.g., Terrvik (2001) and Gunn and Mont (2014), in Lehner (2015)).

The outward driver for sustainability focuses on how firms will 'do the right things' in order to comply with consumer expectations, where cultural and political perceptions guide expectations for sustainability of the food items. Lehner (2015) refers to sense-making to help understand this process. Changes in consumer behavior are often driven by issues such as food scares, health trends, climate change and other emerging environmental challenges. There has been a gradual shift from a perception that society can regulate itself out of all types of common problems, towards a rise in corporate social responsibility - manifested as an increasing requirement to explicitly address sustainability (Carson and Rønningen, 2016). This corporate responsibility for sustainable practices adds a novel dimension to the firm's predominant role of providing profits for their owners.

While the 'do things right' approach has an inward focus, the 'do the right things' approach has an outward focus, in which firms apply various organizational strategies to capture emerging movements and transformations among the stakeholders.

\section{Theoretical Approach: Discursive Legitimizing Strategies}

Sustainability exhibits characteristics of meta-governance, i.e. soft regulation that requires local interpretation in order to impact action (Waldorff, 2013: 284). This interpretation by local agents varies and depends on an understanding of what sustainability is in a particular context. Our aim is to analyze the micro-sociological processes that play out when salmon farmers explain and defend their actions as sustainable in response to a perceived external demand, in order to be recognized as a sustainable business.

Within institutional logics theory, behavior at the individual and organizational level is understood as embedded in a wider social context, characterized by reciprocity between agency and structure (Friedland and Alford, 1991; Thornton et al., 2012). We employ institutional logics to study how the firm makes sense of its environment (Thornton and Ocasio, 2008; Thornton et al., 2012). Constriction of the economic reality is a common explanation for the partial implementation of sustainable practices. Institutional logics allows us to study the mechanisms that firms employ to absorb (or not) elements of the sustainability concept. This literature focuses on the interaction of action, decision, explanation, and interpretation. The premise of this interaction is best expressed in the words of Cyert and March (1963) - that the firms are rational, but bounded.

Individual practice explains how companies incorporate aspects of sustainability in their daily practice. According to the institutional logics literature, practice "... refers to forms of constellations of socially meaningful activity that are relatively coherent and established" (Thornton et al., 2012: 128). Sustainability requirements affect the performance of the salmon farmers and their explanations of this performance, in accordance with Giddens' practice theory (1984). Practice theory focuses on everyday individual life and how it plays out within the confines of the external framework - the discourse (Powell and Rerup, 2017). Discourse includes a wider understanding as well as symbolic factors that determine appropriate decisions and actions. 
Sustainability requires action that resonates with the power-centers of the firms' institutional peers. Firms must therefore make sense of their actions and interpret these actions and decisions in a way that is meaningful for their constituents. Sense-making is the social process where the actors rationalize what they are doing, "interpret their environment in and through interactions with each other" (Maitlis, 2005: 21). To behave rationally, the firms must interpret, translate and act upon the cues from the environment (Powell and Rerup, 2017: 320; Weick, 1995; Weick and Quinn, 1999; Weick et al., 2005). This legitimation process can follow two directions, either strategic or institutional (Suchman, 1995). In the strategic version, legitimacy is a resource that the actors extract from their environment to pursue their goals. The institutional view, on the other hand, perceives legitimacy as constituted by cultural factors in its environment (Suchman, 1995: 576). In this paper we lean towards the strategic approach. A discourse is not one singular unity which is valid for all firms in an industrial field - there might be several layers of discourses depending on the concrete industrial set-up, historical background, or product and markets. Within the framework of the strategic approach, we study how firms go about legitimizing their actions by associating what they do with elements in their layered environment.

The sustainability requirement comes in two guises. Sustainability demands may be embedded in policies and regulations that are interpreted by national regulative authorities. Conversely, consumers may make direct claims on the sustainability of products in the form of sharpened market demands. In this study, we have identified two overarching drivers for sustainability. In the 'do things right' model, we emphasize laws, regulation, public policies, and other directives. In the 'do the right things' model, consumer acceptance, product content, food ethics, labeling, open information sharing, etc., take center stage. How are different aspects of sustainability translated into daily practices that develop into legitimate options for action, accepted by the firms' peers? How are the things we say about sustainability used to justify the foundation for organizational change? This line of argument emphasizes the actors' use of discursive legitimizing strategies (DLS) (Vaara et al., 2006; Van Leeuwen and Wodak, 1999; Waldorff, 2013).

Within the soft governance of sustainability, the use of DLS determines whether sustainability is dismissed or translated one way or the other. How the actors talk about sustainability determines the direction in this transformation. Waldorff (2013) identified five strategies in this sense-making process: normalization, authorization, rationalization, moralization and narrativization (Table 1).

Applying the DLS framework to the analysis of the interviews brings out how relevant actors consider sustainability and identify their legitimate ground for sustainability action, i.e.,

Table 1 Discursive Legitimizing Strategies (DLS) (Waldorff, 2013)

\begin{tabular}{|c|c|c|}
\hline & Strategy & Operational characteristics \\
\hline I & Normalization & $\begin{array}{l}\text { refers to / compares with similar cases or endings that exhibit so-called normal function or } \\
\text { behavior. }\end{array}$ \\
\hline II & Authorization & $\begin{array}{l}\text { refers to / compares with people who are supported by institutionalized authority, cf. laws, } \\
\text { regulations, conventions, etc. }\end{array}$ \\
\hline III & Rationalization & refers to / compares with a means-end rationality, related to profit, purpose, function, etc. \\
\hline IV & Moralization & $\begin{array}{l}\text { refers to / compares with when it is based on moral or ideological grounds with reference to } \\
\text { specific (moral) values. }\end{array}$ \\
\hline $\mathrm{V}$ & Narrativization & $\begin{array}{l}\text { refers to / compares with narrative structure over time and action to dramatize concrete } \\
\text { events. }\end{array}$ \\
\hline
\end{tabular}


how they explain their position when sustainable practices are required. Firms cannot afford to be completely oblivious to the concept of sustainability. They must legitimate their actions and practices within the 'soft framework' and hence translate their position into the sustainability discourse. Even if the framework is 'soft', the commitment is binding for the actors.

\section{Methods}

We conduct an exploratory case study where the study objective is how (or to what extent) sustainability is translated into a meaningful representation of the salmon farmers' actions (see Yin, 2009). Here, we use a bottom-up approach to assess how firms justify their decisions (see Weick et al., 2005). The case material and primary data source are eight semi-structured indepth interviews with a selection of representatives of the Norwegian salmon-farming industry (Table 2). Five of them represent major fish-farming companies ("Big 5"), one fish-feed supplier, and two representatives of industry associations. Secondary material is drawn from white papers on regulations and policies associated with sustainability practices, and other relevant documents. This material is supplemented with data from publicly available documents, reports and statistics. This triangulation ensures good reliability and validity in our study. We employ a purposive sampling strategy, which allow us to choose units where the chance to find the process under scrutiny is greatest (Silverman, 2014). Our purpose is directed by the informant's construction of arguments for their choice of sustainable action.

The discursive legitimizing strategies (DLS) approach focuses on the analysis of how actors strategically use language to provide context for further action (Waldorff, 2013). Strings of text were extracted from interviews and sorted according to the five strategies. We see the five strategies as layered in the sense that strategy choice may vary among situations. Specifically, we address the following questions: How do representatives of the salmon-farming industry perceive the concept of sustainability? Why are decisions made in favor of sustainability (or not)? How are these decisions justified? What do the decisions mean for the context of new decisions? What significance do actors assign to their decisions? We analyzed how and to what extent human and organizational behaviors adopt the environmental, social, and economic prerequisites of the sustainability concept (see Elkington (1994)), i.e., how the industry actors translate sustainability in order to make it manageable. We build on Phillips et al. (2004) and focus on the reciprocity between text, discourse and action in order to explain how the actors choose to talk about sustainability. Keep in mind the soft governance of sustainability; firms will enact only the elements of sustainability that suit their reality. This approach is built on interpretation (epistemology) and construction (ontology) (Bryman, 2016), hence the study is

Table 2 List of informants

\begin{tabular}{ll}
\hline A & Big 5, Fishfarming company \\
\hline B & Medium, Fishfarming company \\
C & Big 5, Fishfarming company \\
D & Big 5, Fishfarming company \\
E & Big 5, Fishfarming company \\
F & Fish feed producer \\
G & Interest organization \\
H & Interest organization \\
\hline
\end{tabular}


both exploratory and inductive. Bryman (2016) reminds us that "people attribute meaning to behavior".

\section{Analysis: How Do the Actors Legitimize their Choices?}

\section{Normalization}

A normalization perspective examines how experiences from the informant correspond to experiences from comparable cases. A reference to other actors' choices of behavior expresses the "normality" of the choice. Sustainability will not stand out as anything extraordinary, but rather as common sense. Normalization can be expressed as 'safety in numbers' i.e. practices similar to 'what everybody else is doing,' or the status quo. Approval from international, nongovernmental organizations (INGOs) such as the Aquaculture Stewardship Council (ASC) is frequently cited as favorable documentation of qualities associated with sustainability (Schouten et al., 2016). The initial investment required to meet the standards is high, and hence only an option for a few actors. However, association with comparable firms contributes to the legitimation of the decision to acquire ASC certification of sustainable qualities.

" ... are the three Norwegian companies with the most ASC approvals at the moment. I guess only $10 \%$ or less currently manage to run their business in accordance with the ASC.” (A)

A more active approach is to consider the interdependencies within the community. Continuation and coexistence are important values: others in the community depend on your action and hence you cannot depart too far from the common ground. These interdependencies have a functional component - the common pen technology is open and connects the farmers to each other and the surrounding environment through the free flow of sea water. Diseases and lice infestation in one farm will affect all its neighbors. It is crucial that infection of salmon lice in wild salmon smolt on their way out from the rivers be prevented. This is an important value argument for the farmers, but it is unclear how they intend to achieve this goal.

"If our neighbors struggle with fish health or their reputation, their struggles are negative for us." (C)

"Diseases easily infect the neighboring fish cage, and because of this, our industry has a lot of voluntary cooperation on such matters." $(\mathrm{H})$

"The government is very concerned with the vulnerable period when the smolt leave the rivers and head for the open sea. ... We do not want to infect the wild salmon. This is an important sustainability issue." (A)

The interdependencies are emphasized with reference to the importance of coexisting with other users of the coastal zone, such as the fishers, tourists and homeowners. According to the Aquaculture Act [2005], the salmon farmers do not have permanent ownership of their farm site, hence they depend on a stewardship of the coastal zone in cooperation with other legitimate users.

"Co-existence is important, and because of that, we participate in partnership with fishers ..." (B) 
The normalization strategy is emphasized by referring to one's own action as a continuation of old praxis. In this way, the salmon farmers legitimize their actions and positions in the community of salmon farmers.

" ... we have eight postulates, ... One of them is "Sustainability in everything we do", and this reflects our approach." (D)

The normalization strategy bases legitimacy on exemplarity, either 'prospective' or 'retrospective' (Vaara et al., 2006). The approach has broad support in the history and self-identity of the salmon farmers, where the business has always been seen as sustainable - taking place in 'pristine waters' and using natural ingredients.

\section{Authorization}

Reference to an Authority Is an Efficient Way to Ensure Legitimacy (Vaara et al., 2016; Van Leeuwen and Wodak, 1999). The Authority Maintains a Powerful Position that Sanctions the Legitimation of the Subject. The Location and Type of Authority May Vary. It Can Be Impersonal, Such as a Regulation or a Sanction, or it May Refer to a Specific Role, I.E. Priest, Adviser, Expert, Teacher (Van Leeuwen and Wodak, 1999). Authorization Is Obviously an Important Legitimizing Category for Norwegian Salmon Farmers. The Government Has Ambitions for the Seafood Sector and Uses Laws and Regulations to Launch New Modes of Production for the Farmers to Consider.

"The industry faces several regulations concerning the environment, and we are required to conduct regular external controls." $(\mathrm{H})$

Sustainability increasingly informs public policy and regulative initiatives closely track this trend. The overlap between governmental regulative initiatives and industry interests highlight sustainability regulation as an important arena for negotiation. Many fish farmers continue to participate in the "green" or "development" concession programs (see above). Farmers also see new business opportunities arise, and yet others see the sustainability programs as addressing the sum of their concerns, and thus as an acceptable option.

"We always follow the regulations, and if we disagree with certain parts of them, then it

is our job to improve them, not work against them." (H)

While salmon farmers tend to be loyal to the regulations, voluntary endorsement forms the foundation of effective sustainability standards, and reflects how farmers appear to consumers in the marketplace. The farmers might propose a particular market orientation and even claim to respond to a consumer interests in sustainability practices by adhering to the standard. Farmers also expressed skepticism, however, about whether market demand truly reflects these more stringent standards.

"However, we do question the reason for some of the certificates that are being made. Many of them are highly market oriented. I do not think that all of them have been requested by the market." (B)

"Certain aspects of this standard push us, while other aspects only appear as semi-wise to us. We have to follow the standard, but we do not always believe that all the guidelines lead to the most sustainable solution in every situation." (D) 
The modern market for salmon and salmon products is predominantly global, and processors must be aware of the requirements of the largest buyers in order to survive in this competitive market. Labelling schemes, certifications and standards are common devices for the trade of farmed salmon. With the emergence of the sustainability concept, the trade of information through such standards is rapidly expanding. Mass media publishes "food scares", and the industry counters using international certificates and standards.

"Norway has its laws, but the standards are global." (A)

Most farmers are supportive of third-party verification of sustainability requirements. This strengthens the legitimacy of these standards and is important for the impact of sustainability claims in the market. The Global Salmon Initiative (GSI) and the ASC are the most prominent standards for sustainable production of salmon.

"This GSI collaboration has sustainability as an important focus area. Many of the large players in the industry participates here.” (D)

"Our goal is to have a completely ASC certified operation." (A)

"Having a third party that comes in and verifies that we have followed all this rule and that our way of operating is in accordance with a standard, is good. ASC are extremely thorough ..." (A)

"... selling to the end-consumers to be able to market its products as ASC approved. In order to do this, all previous steps of the production have to be ASC approved." (A) "This standard has definitely led to changes in the production and the technology in the industry, and the social aspect has been included. ... We score well on aspects such as workers condition compared to many other countries. However, this standard is rigorous when it comes to the environmental aspect." (A)

Surprisingly, the driving force behind adherence to these standards is not short-term market demand. Fish farmers adhere to standards in order to provide documentation of sustainable operations, but, paradoxically, the market is not immediately willing to compensate farmers for this extra certification.

"Our ambition is to have all our facilities certified according to the ASC standard. However, we do not experience any demand for this in the market, nor a willingness to pay more for products produced according to the certification." (C)

While adhering to higher standards may produce few immediate rewards, the formalization of sustainability may be driven by the fact that it is disadvantageous to be the one (or one of the few) that does not adhere to any sustainability program or standard. Being the odd one out may cost more than it is worth. Some farmers are critical of the emergent sustainability scripts - the lack of increased market demand for sustainable labelling has not gone unnoticed by farmers, who point to systemic explanations for their adaptation to sustainability requirements.

"We want to certify our facilities, but it is both time and capital intensive to do so. Each facility has to be certified separately by accountants that have to spend up to a week on the facility." (C)

"My impression is that many actors jump into certificates only to satisfy the system ..." (B) 
“... we felt that they (GSI) focused a lot on issues that were not relevant to us, so we chose to withdraw." (D)

"The paperwork is currently too time consuming and has a too high cost compared to fish farmers in other countries." (B)

Although authorization mainly works through direct sustainability requirements, indirect authorization occurs as well. The salmon-farming industry is a well-organized value chain, and the adherence to sustainability practices is a prerequisite to participating as a sub-supplier in the industry where others may require sustainability certification.

"We do not produce our own smolt and accordingly have to buy this from different suppliers. If the supplier is not approved, our fish will not get the approval either." (A)

"We focus on communicating how we define sustainability and our actions to make our business as sustainable as possible. It is important for us to publish our reports and have accountant approved sustainability reports." (C)

The authorization category may be used as a long-term strategy to win market shares based on documented sustainability factors. Some firms cherry-pick components from among the hundreds of standards and specialize in accordance with these.

\section{Rationalization}

Rationalization and efficiency are important aspects of running a business, and hence there are rational arguments in support of choosing a sustainable strategy. Rationalization achieves legitimacy when it is demonstrated that actions are motivated by lowering costs or in other ways streamlining the operation. The arguments are linked to knowledge-based requirements (Vaara, 2014). Sustainability, as introduced in this perspective, is used to achieve rationalization gains.

"Often efficiency and sustainability are two sides of the same coin." (D)

"The projects have to be specific, measurable, relevant, and time specific." (B)

"... we always strive towards developing better ways to do things. ... Ways that we

believe are better for the future. When we do this, sustainability is a natural outcome."

(D)

While some informants reported that they did not see a market demand for sustainability certification (see above), there were divergent viewpoints. Streamlining the operation in terms of sustainability is certainly a driver for some actors. Again, we see that large-scale buyers can influence outcomes.

“. .. but so far, the market has been willing to pay for the cost of operating according to the ASC. We see several customers paying attention to the quality of their salmon. IKEA is a good example. They do not want anything else than salmon of the best quality in their warehouses." (A)

The business aspect is obviously important for several informants, and this aspect drives the rationalization argument for legitimation. Salmon farmers ask themselves: What do the 
customers want? How can we produce it? How can we catch emerging market trends? How can we promote ourselves in those markets?

"Our main focus at the moment is to get the green licenses up and running and exploit the potential we have received through these licenses from the government." (A)

"Our goal is to get as close to the end customer as possible." (A)

"We believe that as long as you have demanding customers, you will get good feedback." (A)

"Choosing a sustainable approach leads to business. At some point, this will become mainstream. Now, it is a source of competitive advantage." (F)

" 'Lifestyles of health and sustainability' is a new and challenging markets segment we are trying to reach. This segment is characterized by a shared interest for the food purchased and the wish to contribute in a positive manner. Now this segment is insatiable." (F)

"We have also seen a development from spot-market and retail, to more in house and ownership of products and brands, such as Lerøy promoting their salmon. Not just Norwegian salmon.” (F)

Firms perceive the importance of appearing to be responsive to sustainability requirements. Responding to this requirement is not just about producing more sustainable salmon but connects to all other aspects of the value chain; feed content and processing, breeding and genetic improvement, and farm technology are current traits of development that are defended by rational arguments.

"The fish oil we use is sustainable. So is the algae oil. We are proud of our new product. Some customers are already on board, eager to try out this new product, even though the price is still high as it has yet to reach a critical mass in production." (F)

"Finding the right way to brand this type of fish farming will be important. We have to move the focus away from "sterile" and towards "sustainable" when selling triploid fish." (A)

"There are basically three solutions: move production to solid ground, improve today's solution or move to open waters. We have chosen the last alternative and hope to develop new technology for this solution ...." (A)

Fish farmers also address the appropriateness, the miscommunication, the confusion and the ultimate lack of functionality associated with the concept of sustainability. Farmers display concern for the lack of attention to local environmental conditions that stem from the use of open-pen technology, and how it can be improved. Niche production does not necessarily motivate farmers.

"We also work with large on-land projects with smolt, such as the one at Senja. These projects require a lot of technology for recycling of water." (D)

"We hope to be able to take the salmon further away from the shore with technology that can withstand the rougher conditions." (D)

"Many challenges to the development of green technology." (E)

"The establishment of "traffic light" scores for the quality of different areas are currently being discussed. This may be a good idea, but a negative aspect of the arrangement proposed by the government, is that your neighbor's performance will affect your score. This has led to collective protests from the fish farmers." (C) 
Farmers that apply the rationalization argument are primarily driven by business arguments, aiming to satisfy a demand for sustainable products and at the same time sustain the requirements of a modern business. There is visible opposition to the main drivers of adapting to omnipotent sustainability requirements as they are presented in the standardization schemes, and these farmers view it as rational to adapt to a selection of components.

\section{Moralization}

In this category, legitimation refers to specific values and value systems, most visibly delegitimizing purposes (see Vaara et al. (2006) and Vaara (2014)). Van Leeuwen and Wodak (1999) differentiate between moral abstraction and straightforward moral evaluation. In moral abstraction, a text that appears to be an explanation of what is going on is in fact a carefully formulated moral argument (Van Leeuwen and Wodak, 1999).

Salmon farmers may oppose the set of values represented by their customers. At the same time, they acknowledge that the customers are buying their product and hence they "doublecommunicate" their position on this issue.

"Right now, we observe that the customers like our product, but that they are skeptical to the way it is produced. It is almost a trend to be opposed to the fish farming industry, and at the same time, go home and enjoy a meal of sushi." (H)

From the salmon farmers' perspective, this position can be met with knowledge, documentation, and communication.

"We need more research so that we can provide documentation that supports our work."

(A)

The call for more research to take on the role of a (moral) referee is interesting, as it puts pressure on the research establishment to provide the 'right' results.

One informant also pointed out the lopsided distribution of the documentation requirement as compared to, for example, fishers who are essentially hunters at sea and subject to different requirements than the fish farmers, who participate in an organized food industry. Both actors, however, frequently come from similar backgrounds, or even the same community.

"We find it frustrating that some fishers can come up with claims without having any documentation, while we have to document everything." (B)

When salmon farmers argue that they are focusing on sustainable strategies, an important driver is that they want to prevent leaving "footprints" in nature. Ironically, the moral argument behind the initiative to produce triploid salmon that will not reach sexual maturation, is to limit interbreeding with wild populations, despite strong criticism from environmental groups for the use of "modified" organisms. Should farmed salmon escape, they will remain immature and will not end up in the rivers, preventing interbreeding with wild salmon, the threat of which is considered a major problem and one main source of conflict with the public.

"And most importantly, our fish will not affect the environment if they were to escape."

Salmon farmers want to appear sustainable, and their responses show that many are looking for different solutions to conform to a more sustainable industry. The "do the right things" imperative leads to a focus on the farmers themselves and how to pull the right levers to get 
the operation on a sustainable track (according to the present sustainability definition). Hence, we see a moral argument developing within the salmon-farming industry; the relationship with nature is a shared value with the rest of the society, which can be decisive for the actions the farmers themselves make in their own operations. This standpoint is fundamental to sustainability to avoid the destruction of resources necessary for the lives of future generations.

"Oh yes, I believe that the civil society is starting to realize which actions we should undertake to take care of the environment, and which are less efficient." (D)

"We should conduct our business in a sustainable way, making sure not to take from future generations." (A)

"We want to do this forever, and that means that we cannot conduct our business in a way that indicates that we cannot be here in 15 years. That is our main driver. ... Avoid deteriorating our surroundings." (D)

"I believe that stakeholders and NGOs are the groups pressuring the industry on a global level. ... We must do things right the first time. ... When it comes to environmental issues, we have to do everything correctly. We cannot operate as was common earlier." (F)

"Doing things right pays off, and in April, we received a supplier award for "Product with a Purpose". That was a proud moment. ... The fish produced with this feed is sold as a premium product at Wholefoods." (F)

Economic value as a legitimate basis for sustainable operations provides the opportunity for many to argue that Norwegian practices are good enough as they are. For various reasons, many Norwegian salmon farmers have reached a plateau. They consider these questions as 'resolved', under control, and continuously managed in a good way - their perception is that they already "do things right". They fulfill all formal requirements, and believe that their own practices can legitimately be described as sustainable.

"There are many reasons. One is the concern for our reputation. Another is the economic benefit of running a green operation. A clean coast is important for our profit. ... A green operation gives high quality fish with fewer diseases.” (B)

The social component of sustainability was more difficult for many informants to grasp. Social aspects encompass treatment of workers, worker safety, and parental and sick leave, rights that are largely maintained through strong labor unions in Norway. As most fish-farming companies are well organized under Norwegian law, building on long traditions of fishing and farming, informants assumed that the social components of sustainability were maintained as an embedded value in the Norwegian context. Beyond consideration of workers' rights, there were few other issues that were emphasized when it came to social sustainability. Tax schemes, reorganization of value creation, free establishment in the common coastal zone, impact on labor wages, settlement patterns, etc., were largely perceived as unproblematic. However, some expressed an objective of staying in business (providing local jobs) as a form of social responsibility

"Working conditions for our employees and the existence of working unions. These things are usually in order in Norway." (D)

"Furthermore, we also think about society at large when referring to the social aspect. (of sustainability)" (D)

"The industry depends on sustainable development. If it cannot respond, the industry may shut down." (E) 
The intractable problem with salmon lice currently facing the industry illustrates yet another social aspect of sustainability, acting as a driver with significant moral implications by butting up against the reluctance to accept gene-edited organisms such as triploid and sterile fish. This request from the government has moral implications associated with the possible adverse environmental impact of escapees. In addition, there is currently a softening of the resistance towards gene-editing methodologies in food production in Norway (Bioteknologirådet, 2018). The search for solutions to environmental problems within the salmon-farming industry may create an opening for this technology.

"The Norwegian government currently sees lice and the mixing of farmed and wild fish as the biggest threats to sustainable production. As such, they want us to use sterile fish and this was one of the reasons to why we got these green licenses. They want us to find good ways to implement triploid fish in the industry." (A)

We see that while salmon farmers are concerned with sustainable development, they have a seemingly unresolved relationship to what it means for them. It is important for the reputation of the salmon farmer, and hence it is important for the bottom line of the operation. Moreover, it is important for salmon farmers to emphasize that the operation takes place along a clean (environmentally healthy) coastline, and that their enterprise does nothing to threaten this status. They experience that customers are increasingly concerned with sustainability. Nevertheless - when it comes to customer behavior - the price tag controls consumer choices. It is difficult for farmers to achieve compensation for the extra effort that they put into operationalizing sustainability values.

"We see that some customers care about the green aspect of our products and are willing to pay for it, like in a US contract we have now. Others, say they care, and then in the end, when signing the contract, it turns out to be less important. You don't necessarily get payed for delivering green products." (D)

As a result, any moral argument used to legitimize sustainability hinges largely on the salmon farmers' relationship with nature. The moral argument thus becomes a (somewhat cynical) balancing of accounts - business owners want to operationalize their values to the extent that they can afford it. How much morality can we afford?

\section{Narrativization}

The narrativization legitimizing strategy is based on establishing stories (narratives) that show how activities are part of relationships along a time axis, linking events to the past or the future (Vaara, 2014). Here, the legitimation process builds on storytelling - stories that help provide explanations through promoting interconnection between experiences. The narratives legitimize strategies that are made to fit with a given narrative (Van Leeuwen and Wodak, 1999). In other words, actions and events are given meaning by how they are translated. The texts may convey "dramatic narrativization" (Vaara et al., 2006) where actors are portrayed as winners and losers, bridging decisions the firm is taking with what other firms are successfully achieving. A common starting point for this legitimate argument is that Norwegian salmon farmers claim to have worked well with quality and continue to do so.

"Still, Norwegian production generally has a high level of quality, especially in the north." (A) 
One problem for the salmon farmers is that the power to define sustainability has been left to market groups. Many salmon farmers interviewed articulated frustration over measures of sustainability that were put in place by those they felt had less knowledge and expertise than the farmers themselves. In contrast, the narrativization strategy dictates that sustainability has been an integral part of their operations long before it became a separate quality criterion imposed by the authorities.

"Sustainability has always been an integrated part of our operation. If you pollute the water, you pollute your facility. If you extract too many resources for feed, you will not have any tomorrow. It is very easy to connect sustainability to our bottom line." (C)

There is a perception among the salmon farmers that public attitudes to farming have evolved over time - from general opposition to all fish farming as a source of food, to a specific focus on how best to produce food in fish farms and, hence, potentially affect the way in which it is done.

" ... the focus of the attention has shifted from the question of whether we should have fish farming or not, and towards an acceptance of the necessity of fish farming and then the question of how to best conduct aquaculture." (C)

An important element in the "do things right" perspective is how a sustainability policy can be operationalized and influence salmon farmers to behave sustainably. In this perspective, technology becomes important. Technology is a field the authorities can influence through use of financial tools or regulation. The underlying premise is that salmon farmers amend their behavior to stay in line with the governing authority. As addressed above, various initiatives have used licensing policy to influence technology choices, such as farm technology or biotechnology. Currently, there is a push to promote development and use of open-ocean (offshore) farms, presented by the authorities as a continuation of the long tradition of positive technological developments among Norwegian salmon farmers. Open-ocean farms utilize facilities that are further out at sea, where ocean currents are assumed to mitigate detrimental effects of waste products and other environmental stressors to the extent that the impact will be negligible.

A high-tech narrative is associated with development concessions (see above) and technology development. The narrative is developed through an alliance between government and industry, with a push for sustainable production technologies for the salmon-farming industry as the driver. Furthermore (and perhaps more importantly) is that Norway has engineering expertise available, due to the recent decline in oil and offshore sector. In other words, this diagonal integration in relation to the oil and offshore is a possible win-win situation for Norway.

"Our next focus area will be the development concession. The government wants us to make use of new technology to be able to use new areas for fish farming." (A)

" ... the engineers from the offshore industry coming to us are suggesting solutions and collaboration in a search for new markets." (A)

"The tougher situation in the oil industry, combined with the growth in the fish farming industry, makes a lot of new firms enter the market. With a yes or no to an application, the government holds the key to a lot of work places." (A)

"Finding new technology that can endure tougher conditions on more open water in wild salmon's natural habitat, is a goal. ... The offshore industry has experience in handling these rough conditions. We hope that combining knowledge from the offshore industry with knowledge from the fish farming industry will result in an innovative solution to the problem." (A) 
Critics argue that this cross-fertilization will not be successful in the long run because the external players are unable to familiarize themselves with the specific aspects of farming and will, hence, introduce solutions that are far too costly for the industry.

"Technology or other things may make a sustainable solution the right path to choose. Let's take the offshore fish farming project. ... We see that our competitors pop up with new ideas on how to solve the issues. Their ideas are fostered by the possibility to apply for the development permissions...These projects are extremely costly. We believe that several firms should get the opportunity to test different technology and innovation." (D)

Utilizing technology development is not an easy way out. There are many solutions in other industries that can be applied to fish farming, but optimization will take time - although the Norwegian industry's history in this field is strong, development will undoubtedly be costly.

"I believe it will take a long time to develop the necessary technologies.... The next step will be to evaluate and adjust and decide upon the best method for reaching our goal of feeding everybody in 2050." (A)

"Well, we are typically not perceived to be as intimidating as larger firms are. Start-ups often prefer to approach firms like us, and their ideas are important for the development of the industry. We can cooperate closer with start-ups." (B)

"I think the fish farming industry could have been better at adopting technology from elsewhere." (B)

Norwegian salmon farmers are concerned with their own histories and often associate legitimate arguments with how they and others have been occupied with what they perceive as sustainable production for many years. One aspect of this is technological development that is primarily driven by the relationship between the salmon-farming actors and the authorities, where projects incorporating new technology are based on Norway's traditional competence within marine industries.

\section{What the Stakeholders Talk about when they Talk about Sustainability}

Norwegian salmon farmers employ a series of strategies to legitimize their choices. In order to elucidate how individual farmers explain their approach to sustainability, we organized the information from the interviews according to descriptive behavioral characteristics within a critical discourse analysis framework (Table 3). Sustainability is a form of soft governance, and change depends on the translation and transformation of existing practice.

The first behavioral category, passive adaptation to perceived external requirements - either regulative or normative - is mirrored in a discourse that relies on compliance to formal regulations or directives from certification bodies. Normalization and authorization are the main legitimizing

Table 3 Main behavioral categories in relation to discursive legitimizing strategies

\begin{tabular}{llllll}
\hline & Normalization & Authorization & Rationalization & Moralization & Narrativization \\
\hline Passive adaptation & Significant & Significant & Less significant & Insignificant & Insignificant \\
Awareness / sensibility & Less significant & Insignificant & Undetermined & Significant & Less significant \\
Cooperation / progressive & Less significant & Insignificant & Significant & Significant & Less significant \\
Opportunism & Less significant & Insignificant & Less significant & Insignificant & Less significant \\
\hline
\end{tabular}


strategies for this category. The next category, awareness / sensibility, is more complex and comprises awareness for consumers and for the ecosystem, i.e. external factors. In general, this is perceived as a moral issue where the obligation towards these groups gives directives for choices of legitimizing strategies. The cooperation / progressive category indicates a behavior driven by agency, i.e. a desire to actively change practices. This agency may be organizational or associated with innovation, research and knowledge development. Both rationalization and moralization strategies will support this category. Finally, opportunism is the behavioral category designated for the free-riders that explain their project as green without complying with any of the requirements.

In order to operationalize the association between practice theory and sustainability, we adhere to Teece (2007): how do actors sense, seize and reconfigure sustainability? We partly expand upon existing work on discursive constraints on the greening of the aquaculture industry (Christiansen and Jakobsen, 2017; Fløysand et al., 2016; Fløysand and Jakobsen, 2017). While earlier work has constructed narratives to explain various strategies for the greening process, we argue that the earlier emphasis on politics creates a bias of predetermination in the narratives that disguises important conforming factors and, hence, the ability to analyze the action of each firm and the accumulated impact of each action. Firms with strong dynamic capabilities have the capacity not only to adapt to the principles of the sector, but to confront and change dogma behind current practices through entrepreneurial activity, innovation and association with partners in other industries (Teece, 2007).

The authorities and the big salmon companies (the big 5) are engaged in a power struggle when it comes to owning and controlling sustainability within salmon farming, i.e. how farming practices should be defined and further developed. The two groups have different agendas. On the one hand, the government's drivers are the drying up of available near-coast sites for open-pen farming, plus and the availability of advanced off-shore technology and expertise (derived from the sunset oil industry) potentially useful for open-ocean farms. The political instrument is the implementation of a more lenient economic (?) framework for those who join the effort. The 'big 5', on the other hand, are involved in open-ocean farms, but also push cost-driven private certification schemes and markets - having activities in a range of countries with varied conditions and sustainability requirements.

Sustainability is a general term that needs to be contextualized in order to make sense. Practice creates routines and - when they reinforce their importance - rationalized rituals. When it comes to the approach to sustainability among fish farmers, there are different routines with different origins and historical backgrounds. Among other things, the companies have different economic and political muscles they can flex to boost their own strategies, as illustrated in the example of ASC certification where the actual cost of certification may be a prohibitive factor. The 'big 5' use resources to get some or all of their farm facilities certified. This process is expensive, and often does not provide immediate profit in the market; the market is unwilling to pay. So why are the 'big 5' pushing for certification? One obvious benefit is the ability to push smaller companies out of business and hence control the market. The largest firms see sustainability strategies as an intangible extension of product quality and something that the market will pay for in a long-term perspective.

What are the implications of this analysis? When it comes to sustainability strategy, one size does not fit all. Sustainability is a flexible ideal (e.g. soft governance), reflected in the great diversity in approaches we rapport here. One advantage to this diverse relation to sustainability, is the potential stimulation of different drivers for a new sustainability paradigm in the future. In an organizational ecological perspective, for example, one may claim that if 'the big 5' acquired the exclusive right to define sustainability, then important perspectives from the smaller businesses would disappear such as cooperation with the local community. Sustainability is not a neutral term. The strategic use of the concept and the power to obtain a' sustainability status' is important. 
Funding Information Open Access funding provided by NTNU Norwegian University of Science and Technology (incl St. Olavs Hospital - Trondheim University Hospital).

Open Access This article is licensed under a Creative Commons Attribution 4.0 International License, which permits use, sharing, adaptation, distribution and reproduction in any medium or format, as long as you give appropriate credit to the original author(s) and the source, provide a link to the Creative Commons licence, and indicate if changes were made. The images or other third party material in this article are included in the article's Creative Commons licence, unless indicated otherwise in a credit line to the material. If material is not included in the article's Creative Commons licence and your intended use is not permitted by statutory regulation or exceeds the permitted use, you will need to obtain permission directly from the copyright holder. To view a copy of this licence, visit http://creativecommons.org/licenses/by/4.0/.

\section{References}

Aarset, B., and S.-E. Jakobsen. 2009. Political regulation and radical institutional change: The case of aquaculture in Norway. Marine Policy 33: 280-287.

Asche, F. 2008. Farming the sea. Marine Resource Economics 23: 527-547.

Asche, F., A.G. Guttormsen, and R. Nielsen. 2013. Future challenges for the maturing Norwegian salmon aquaculture industry: An analysis of total factor productivity change from 1996 to 2008. Aquaculture 396: 43-50.

Bioteknologirådet (2018). "The Gene Technology Act - Invitation to Public Debate." Bioteknologirådet [The Norwegian Biotechnology Advisory Board], Oslo.

Bjordal, J. (2011). Organic Salmon farming - an assessment of managerial and organizational implications, and the internalization of environmental externalities. Master Thesis in Economics and Business Administration, Norges Handelshøyskole.

Bronnmann, J., and F. Asche. 2016. The value of product attributes, brands and private labels: An analysis of frozen seafood in Germany. Journal of Agricultural Economics 67: 231-244.

Bryman, A. 2016. "social research methods," 5th/Ed. Oxford: Oxford University Press.

Buchanan, D., L. Fitzgerald, D. Ketley, R. Gollop, J.L. Jones, S.S. Lamont, A. Neath, and E. Whitby. 2005. No going back: A review of the literature on sustaining organizational change. International Journal of Management Reviews 7: 189-205.

Carrigan, M., and A. Attalla. 2001. The myth of the ethical consumer - Do ethics matter in purchase behaviour? Journal of Consumer Marketing 18: 560-578.

Carson, S. G. (2018). The corporate legitimacy matrix - A framework to analyze complex business-society relations. Philosophy of Management online.

Carson, S.G., Ø. Hagen, and S.P. Sethi. 2015. From implicit to explicit CSR in a Scandinavian context: The cases of HÅG and hydro. Journal of Business Ethics 127: 17-31.

Carson, S. G., and Rønningen, K. (2016). Norwegian salmon farming and the chase for social legitimacy. In "food futures: Ethics, science and culture ", pp. 123-144. Wageningen academic publishers.

Christiansen, E.A.N., and S.E. Jakobsen. 2017. Diversity in narratives to green the Norwegian salmon farming industry. Marine Policy 75: 156-164.

Cyert, R.M., and J.G. March. 1963. A behavioral theory of the firm. Englewood Cliffs, N.J: Prentice-Hall.

de Lange, D. E., Busch, T., and Delgado-Ceballos, J. (2012). Sustaining sustainability in organizations. Journal of Business Ethics 110.

Elkington, J. 1994. Towards the sustainable corporation - win-win business strategies for sustainable development. California Management Review 36: 90-100.

Fiskeridirektoratet (2013). Merknader til forskrift om tildeling av løyve til havbruk med matfisk av laks, aure og regnbogeaure i sjøvatn i 2013.

Fiskeridirektoratet (2017). Utviklingstillatelser. Bergen.

Fløysand, A., K. Haland, and S.-E. Jakobsen. 2016. Discourses, risk perceptions and the "green" profile of the New Zealand salmon farming industry. Marine Policy 74: 230-235.

Fløysand, A., and S.-E. Jakobsen. 2017. Industrial renewal: Narratives in play in the development of green technologies in the Norwegian salmon farming industry. Geographical Journal 183: 140-151.

FOR-2004-12-22-1798 (2004). Forskrift om tillatelse til akvakultur for laks, ørret og regnbueørret (laksetildelingsforskriften) [Sist endret 1/10 2017]. Nærings- og Fiskeridepartementet, Oslo.

FOR-2013-06-24-754 (2013). Forskrift om tildeling av løyve til havbruk med matfisk av laks, aure og regnbogeaure i sjøvatn i 2013. Nærings- og Fiskeridepartementet, Oslo. 
Friedland, R., and R.R. Alford. 1991. Bringing society Back in: Symbols, practices, and institutional contradictions. In The new Institutionalism in organizational analysis, ed. W.W. Powell and P.J. DiMaggio, 232-263. Chicago: University of Chicago Press.

Furuset, A. (2018). Liste: Priser og kjøpere i auksjonene. In "Intrafish".

Giddens, A. 1984. The constitution of society: Outline of the theory of structuration. Berkley: University of California Press. Godfray, H.C.J., J.R. Beddington, I.R. Crute, L. Haddad, D. Lawrence, J.F. Muir, J. Pretty, S. Robinson, S.M. Thomas, and C. Toulmin. 2010. Food security: The challenge of feeding 9 billion people. Science 327: 812. Grant, D., Hardy, C., Oswick, C., and Putnam, L. (2004). "The handbook of organizational discourse," Sage, London.

Guerreiro, J. N. P. (2014). Marine harvest \& WWF-Norge - et strategisk samarbeid for en bærekraftig fremtid (marine harvest \& WWF-Norway - a strategic partnership for a sustainable future), Norges miljø- og biovitenskapelige universitet, Ås.

Gunn, M., and O. Mont. 2014. Choice editing as a retailers' tool for sustainable consumption. International Journal of Retail \& Distribution Management 42: 464-481.

Haugen, A.S., S. Bremer, and M. Kaiser. 2017. Weaknesses in the ethical framework of aquaculture related standards. Marine Policy 75: 11-18.

Hersoug, B., E. Mikkelsen, and K.M. Karlsen. 2019. "Great expectations" - Allocating licenses with special requirements in Norwegian salmon farming. Marine Policy 100: 152-162.

Lehner, M. (2015). Translating sustainability: The role of the retail store. International Journal of Retail \& Distribution Management 43, 386-+.

Lubin, D. A., and Esty, D. C. (2010). The sustainability imperative. Harvard Business Review.

Maitlis, S. 2005. The social processes of organizational sensemaking. Academy of Management Journal 48: 21-49.

Manniche, J. 2012. Combinatorial knowledge dynamics: On the usefulness of the differentiated knowledge bases model. European Planning Studies 20: 1823-1841.

Meld. St. 1 ((2017-2018)). Nasjonalbudsjettet 2018. Kap 6 Norges oppfølging av FNs bærekraftsmål. (Finansdepartementet, ed.), Oslo.

Meld. St. 16 (2014-15). Forutsigbar og miljømessig bærekraftig vekst i norsk lakse- og ørretoppdrett. Næringsog Fiskeridepartement, Oslo.

Nærings- og fiskeridepartementet (2015). Nye konsesjoner skal utvikle framtidas oppdrett. In "NFD press release", Oslo.

Nærings- og fiskeridepartementet (2016). Retningslinjer for behandling av søknader om utviklingstillatelse til oppdrett av laks, ørret og regnbueørret. Nærings- og fiskeridepartementet, Oslo.

Nærings- og fiskeridepartementet (2017). Ordningen med utviklingstillatelser opphører. In "NFD press release". Nærings- og fiskeridepartementet, Oslo.

Olesen, I., A.I. Myhr, and G.K. Rosendal. 2011. Sustainable aquaculture: Are we getting there? Ethical perspectives on Salmon farming. Journal of Agricultural \& Environmental Ethics 24: 381-408.

Osmundsen, T.C., and M.S. Olsen. 2017. The imperishable controversy over aquaculture. Marine Policy 76: 136-142.

Peattie, K. (2010). Green consumption: Behavior and norms. In "Annual Review of Environment and Resources, Vol 35" (A. Gadgil and D. M. Liverman, eds.), Vol. 35, pp. 195-228.

Phillips, N., and C. Hardy. 2002. Discourse analysis: Discourse analysis investigating processes of social construction. London: Sage.

Phillips, N., T.B. Lawrence, and C. Hardy. 2004. Discourse and institutions. Academy of Management Review 29: $635-652$.

Powell, W. W., and Rerup, C. (2017). Opening the black box: The microfoundations of institutions. In "The Sage Handbook of Organizational Institutionalism, 2nd Edition" (R. Greenwood, C. Oliver, T. B. Lawrence and R. Meyer, eds.), pp. 311-337. Sage Publishers.

Reinertsen, H., and Haaland, H. (1995). "Sustainable fish farming," A.A. Balkema, Rotterdam.

Schouten, G., Vellema, S., and van Wijk, J. (2016). Diffusion of global sustainability standards: The institutional fit of the ASC-shrimp standard in Indonesia. Revista de Administração de Empresas 56.

Silverman, D. 2014. "interpreting qualitative data," fifth edition/Ed. London: Sage.

St.meld. nr. 19 (2004-2005) Marin næringsutvikling. Den blå åker. Fiskeri- og kystdepartementet, Oslo.

Suchman, M.C. 1995. Managing legitimacy: Strategic and institutional approaches. Academy of Management Review 20: 571-611.

Svalestuen, T. (2013). Bruk av strategiske beskyttelsesmekanismer blant avlsselskaper i norsk oppdrettsnæring Kampen for lakserognen [use of strategic protection mechanisms among breeding in Norwegian aquaculture - the battle for salmon roe], UMB school of economics and Business, Ås.

Teece, D.J. 2007. Explicating dynamic capabilities: The nature and microfoundations of (sustainable) enterprise performance. Strategic Management Journal 28: 1319-1350.

Terrvik, E. (2001). Att kanalisera hållbarhet: hur dagligvaruföretag översätter miljökrav till handling: en studie om egna miljövarumärken i dagligvaruhandeln. $\mathrm{PhD}$ thesis, University of Gothenburg, Sweden. 
Thornton, P. H., and Ocasio, W. (2008). Institutional logics. In "THE SAGE HANDBOOK OF ORGANIZATIONAL INSTITUTIONALISM" (R. greenwood, C. Oliver, R. Suddaby and K. SahlinAndersson, eds.). Sage Publications Ltd, Los Angeles.

Thornton, P.H., W. Ocasio, and M. Lounsbury. 2012. The institutional logics perspective: A new approach to culture, structure, and process. Oxford: Oxford University Press.

United Nations (2015). Transforming our world: the 2030 Agenda for Sustainable Development. (U. N. G. Assembly, ed.), Vol. A/RES/70/1.

United Nations General Assembly (2015). "Resolution adopted by the General Assembly on 25 September 2015. Transforming our world: the 2030 Agenda for Sustainable Development.".

Ursin, L., B.K. Myskja, and S.G. Carson. 2016. Think global, buy national: CSR, cooperatives and consumer concerns in the Norwegian food value chain. Journal of Agricultural \& Environmental Ethics 29: 387-405.

Vaara, E. 2014. Struggles over legitimacy in the Eurozone crisis: Discursive legitimation strategies and their ideological underpinnings. Discourse \& Society 25: 500-518.

Vaara, E., S. Sonenshein, and D. Boje. 2016. Narratives as sources of stability and change in organizations: Approaches and directions for future research. Academy of Management Annals 10: 495-560.

Vaara, E., J. Tienari, and J. Laurila. 2006. Pulp and paper fiction: On the discursive legitimation of global industrial restructuring. Organization Studies 27: 789-810.

Van Leeuwen, T., and R. Wodak. 1999. Legitimizing immigration control: A discourse-historical perspective. Discourse Studies 1: 83-118.

von Krogh, E. (2016). Teknologiutvikling og politiske reguleringer innen lakseoppdrettsnæringen. master, University of Oslo, Oslo.

Waldorff, S.B. 2013. What is the meaning of public sector health? Translating discourse into new organizational practices. Journal of Change Management 13: 283-307.

WCED (1987). "Our common future. The world Commision on environment and development (the Brundtland report)." UN.

Weick, K.E. 1995. What theory is not, theorizing is. Administrative Science Quarterly 40: 385-390.

Weick, K.E., and R.E. Quinn. 1999. Organizational change and development. Annual Review of Psychology 50: 361-386.

Weick, K.E., K.M. Sutcliffe, and D. Obstfeld. 2005. Organizing and the process of sensemaking. Organization Science 16: 409-421.

Wodak, R., and M. Meyer. 2001. Methods of critical discourse analysis. London: SAGE Publications.

World Bank. 2013. Fish to 2030. Prospects for fisheries and aquaculture. Washington DC: The World Bank.

Yin, R. K. (2009). "Case study research. Design and methods," 2/Ed. Sage, Thousand Oaks.

Publisher's Note Springer Nature remains neutral with regard to jurisdictional claims in published maps and institutional affiliations.

\section{Affiliations}

\section{Bernt Aarset ${ }^{1} \cdot$ Siri Granum Carson ${ }^{2} \cdot$ Heidi Wiig $^{3} \cdot$ Inger Elisabeth Måren $^{4} \cdot$ Jessica Marks ${ }^{1}$}

Siri Granum Carson

siri.granum.carson@ntnu.no

Bernt Aarset

bernt.aarset@nmbu.no

1 NMBU, Ås, Norway

2 NTNU, Trondheim, Norway

3 BI, Oslo, Norway

4 UiB, Bergen, Norway 